\title{
PENGARUH NILAI TUKAR RUPIAH SERTA TINGKAT SUKU BUNGA TERHADAP PENERIMAAN PAJAK PADA DIREKTORAT JENDERAL PAJAK
}

\author{
Ai Nety Sumidartini \\ Institut Ilmu Sosial dan Manajemen STIAMI \\ Answara06@yahoo.com
}

\begin{abstract}
Abstrak. Penerimaan Pajak merupakan salah satu sumber penerimaan negara yang paling besar dibandingkan dengan penerimaan dari sektor migas dan penerimaan negara lainnya. Pajak memberikan kontribusi penerimaan sebesar 70,46\% terhadap APBN tahun 2007.

Penerimaan Pajak tidak dapat berdiri sendiri terpisah dari faktor makro ekonomi lainnya sebagimana telah disumsikan pada saat penyusunan APBN, seperti pertumbuhan ekonomi, nilai tukar rupiah, tingkat suku bunga, tingkat harga minyak pada pasar internasional, dan tingkat produksi minyak dalam negeri. Faktor makro ekonomi tersebut bersifat dinamis dan berubah sesuai dengan kondisi perekonomian yang berjalan pada saat itu sedangkan rencana penerimaan Pajak telah ditetapkan diawal tahun sesuai dengan penetapan Anggaran dan Pendapatan Belanja Negara.

Untuk meneliti ada atau tidaknya pengaruh dari perubahan faktor makro ekonomi tersebut terhadap penerimaan pajak, maka pada penelitian ini akan dibahas mengenai pengaruh nilai tukar rupiah, dan tingkat suku bunga terhadap penerimaan pajak pada Direktorat Jenderal Pajak.

Untuk menjawab masalah-masalah tersebut, data dikumpulkan dari berbagai sumber dan dianalisis dengan metode asosiatif (hubungan) yang bersifat interaktif resiprokal atau saling mempengaruhi. Data variabel penelitian dikumpulkan untuk diteliti dengan regresi linier melalui pengujian linieritas dan pengujian asumsi klasik.

Hasil penelitian menunjukkan adanya pengaruh yang signifikan atas tingkat nilai tukar rupiah, dan tingkat suku bunga terhadap penerimaan pajak baik secara sendiri-sendiri ( parsial ) maupun secara bersama-sama (simultan ).
\end{abstract}

Kata kunci: nilai tukar rupiah, tingkat suku bunga, penerimaan pajak, direktorat jenderal pajak

Abstract. Acceptance receiving of Tax is one of source of acceptance receiving of biggest state compared to acceptance receiving from sector migas and acceptance receiving of other state. Tax gives contribution of acceptance receiving 70,46\% to APBN the year 2007.

Acceptance receiving of Tax cannot be independent separated from macro factor of other chartered investment counsel of sebagimana has been disumsikan at the time of compilation APBN, like chartered investment counsel growth, rupiah conversion value, level of interest rate, level of the price of commodity exchange incorporated at international market, and commodity exchange incorporated production rate in country. Macro factor of the chartered investment counsel haves the character of dynamic and changes as according to condition of run economics at that moment while acceptance receiving plan of Pajak has been specified beginning of year as according to pegging of Anggaran and Pendapatan Belanja Negara.

To check whether there or is not there influence from alteration of macro factor of the chartered investment counsel to tax acceptance receiving, hence at this research will be studied about rupiah conversion value influence, and level of interest rate to acceptance receiving of tax at Tax Directorate General.

To answer the problems, data collected from various sources and analysed with associative method ( relationship) is having the character of interaktif resiprokal or is each other influence. Research variable data collected to be checked with linear regression passed testing of linierity and testing of classic assumption. 
Result of research shows existence of influence signifikan to level of rupiah conversion value, and level of interest rate to acceptance receiving of good tax x'selfly (parsial) and also joinly ( simultan ).

Keywords: Rupiah exchange rate, interest rate, tax revenue, directorate general tax

\section{PENDAHULUAN}

Salah satu indikator keberhasilan penyelenggaraan negara adalah dapat dilaksanakannya Program Pembangunan Nasional yang untuk pelaksanaan tahunannya disusun Anggaran Pendapatan dan Belanja Negara oleh Pemerintah bersama dengan Dewan Perwakilan Rakyat. Anggaran Pendapatan dan Belanja negara (APBN) disusun sesuai dengan kebutuhan penyelenggaraan negara dan kemampuan dalam menghimpun pendapatan negara dalam rangka terwujudnya perekonomian nasional berdasarkan atas demokrasi ekonomi dengan prinsip kebersamaan, efisiensi berkeadilan, berkelanjutan, berwawasan lingkungan, kemandirian serta dengan menjaga keseimbangan kemajuan dan kesatuan ekonomi nasional.

Sejak ekspor migas tidak dapat lagi digunakan sebagai sumber utama penerimaan negara maka pemerintah mulai mengintensifkan penerimaan negara diluar migas dengan berusaha meningkatkan ekspor produk-produk non migas dan intensifikasi penerimaan pajak. Intensifikasi penerimaan pajak dilakukan dengan melakukan perubahan mendasar UndangUndang Perpajakan pada tahun 1983 dan melakukan penyempurnaan peraturan perundang-undangan dibidang perpajakan pada tahun tahun sesudahnya.Secara umum Anggaran Pendapatan dan Belanja Negara (APBN) diarahkan agar mampu menjadi jangkar dalam menjaga stabilitas ekonomi makro, dan memberikan stimulus secara proporsional dan terukur sesuai dengan kemampuan keuangan negara. Hal ini diperlukan untuk mendukung akselerasi pertumbuhan ekonomi nasional, dalam upaya mengatasi masalah pengangguran dan kemiskinan, dengan tetap konsisten menjaga langkah-langkah konsolidasi fiskal guna mewujudkan kesinambungan fiskal (fiscal sustainability).

Sesuai dengan Undang-Undang nomor 18 Tahun 2006 tanggal 15 November 2006 tentang Anggaran Pendapatan dan Belanja Negara (APBN) Tahun Anggaran 2007, penerimaan negara dari sektor pajak ditetapkan sebesar Rp. 509.462.000.000.000,- ( lima ratus sembilan trilyun empat ratus enam puluh dua milyar rupiah ) atau sebesar 70,46\% dari Total Penerimaan Negara.

Anggaran Pendapatan dan Belanja Negara (APBN) tersebut disusun dengan menggunakan asumsi dasar ekonomi makro yang telah disepakati sebelumnya, yaitu pertumbuhan ekonomi 6,3 persen, tingkat inflasi 6,5 persen, rata-rata nilai tukar rupiah sebesar Rp 9.300 per dollar AS, tingkat bunga Bank Indonesia (SBI) 3 bulan sebesar rata-rata 8,5 persen per tahun, lifting minyak sebesar 1,0 juta barel per hari, dan harga minyak mentah sebesar 63 dollar AS per barel.

Pada bulan Agustus 2007 pemerintah mengajukan Anggaran Pendapatan dan Belanja Negara (APBN) Perubahan dengan perubahan beberapa asumsi makro ekonomi yaitu pertumbuhan ekonomi 6,1 persen, tingkat inflasi 6 persen, rata-rata nilai tukar rupiah sebesar Rp 9.300 per dolar AS, tingkat Suku Bunga Bank Indonesia (SBI) 3 bulan sebesar rata-rata 8 persen per tahun, lifting minyak sebesar 1,0 juta barel per hari, dan harga minyak mentah sebesar 60 dollar AS per barel. Dengan perubahan tersebut penerimaan dari sektor pajak turun dari 509,462 Trilyun menjadi 454,41 Trilyun.

Dengan memahami bahwa situasi ekonomi global dan nasional akan terus bergerak dinamis yang akan membuat angka asumsi makro tersebut dapat berubah setiap 
saat. Meskipun demikian melalui berbagai langkah dan kebijakan yang terus makin terpadu, Pemerintah akan berupaya agar asumsi makro dalam hal pertumbuhan ekonomi dan inflasi dapat terjaga dan terealisir sesuai perhitungan awal. Sedangkan harga minyak akan mengikuti dinamika internasional, yang artinya perlu diupayakan agar dampaknya terhadap anggaran dan perekonomian tidak terlalu signifikan.

Jika kondisi makro yang mempengaruhi Anggaran Pendapatan dan Belanja Negara (APBN) mengalami perubahan yang signifikan maka asumsiasumsi yang ada pada Anggaran Pendapatan dan Belanja Negara ( APBN) tidak sesuai lagi dengan kondisi yang ada sehingga perlu dilakukan perubahan Anggaran Pendapatan dan Belanja Negara (APBN). Oleh karena kondisi makro yang dinamis maka peneliti memandang perlu untuk melakukan penelitian apakah perubahan kondisi makro ekonomi khususnya yang berkaitan dengan inflasi, nilai tukar rupiah dan tingkat suku bunga berpengaruh terhadap penerimaan pajak

Penerimaan pajak merupakan hal yang sangat berpengaruh terhadap kelangsungan pembiayaan pemerintahan dan pembangunan, dimana di Indonesia pajak mempunyai kontribusi sebesar $70,46 \%$ dari total penerimaan negara tahun 2007 sehingga kegagalan dalam pencapaian target penerimaan pajak akan menyebabkan kegagalan dalam pembiayaan pemerintahan. Dengan diketahuinya pengaruh perubahan makro ekonomi terhadap penerimaan pajak maka diharapkan pemerintah dapat mengantisipasi dan mencari alternatif pembiayaan untuk keberlangsungan pemerintahan dan pembangunan apabila penerimaan pajak tidak tercapai.

\section{Pembatasan Masalah}

Secara umum terdapat dua faktor yang mempengaruhi penerimaan pajak, yaitu faktor internal dan faktor eksternal. Faktor eksternal di antaranya berasal dari faktor makro ekonomi. Faktor makro ekonomi adalah terdiri dari pertumbuhan ekonomi, tingkat inflasi, nilai tukar rupiah, tingkat suku bunga Bank Indonesia (SBI) 3 bulan, lifting (tingkat produksi) minyak per barel per hari, dan harga minyak mentah per dollar Amerika per barel. F aktor eksternal ini tidak dapat dikendalikan oleh Direktorat Jenderal Pajak karena perkembangannya ditentukan oleh mekanisme pasar atau tergantung pada kondisi perekonomian secara global yang meliputi kondisi ekonomi Indonesia, kondisi ekonomi regional maupun kondisi ekonomi internasional secara keseluruhan.

Untuk memudahkan dalam penelitian, peneliti hanya membatasi penelitian pada faktor ekternal khususnya faktor makro ekonomi yang kemungkinan berpengaruh secara dominan terhadap penerimaan pajak, di antaranya adalah nilai tukar rupiah terhadap dollar Amerika, dan tingkat suku bunga. Berdasarkan hal itu, tujuan dari penelitian ini adalah untuk meneliti pengaruh :

1. Nilai tukar rupiah terhadap penerimaan pajak.

2. Tingkat suku bunga terhadap penerimaan pajak.

3. Inflasi, nilai tukar rupiah, dan tingkat suku bunga secara bersama sama terhadap penerimaan pajak.

\section{KAJIAN PUSTAKA}

\section{Pajak}

Secara umum pajak diartikan iuran rakyat kepada negara berdasarkan undangundang sehingga dapat dipaksakan dengan tidak mendapat balas jasa secara langsung. Pajak dipungut pemerintah berdasarkan norma-norma hukum guna pembiayaan umum pemerintah dalam rangka menjalankan fungsi pemerintahan. Menurut P. J. A. Adriani, pajak adalah iuran masyarakat kepada negara (yang dapat dipaksakan) yang terutang oleh yang wajib membayarnya menurut peraturanperaturan umum (undang-undang) dengan tidak mendapat prestasi kembali yang langsung dapat ditunjuk dan yang gunanya adalah untuk membiayai pengeluaranpengeluaran umum berhubung tugas negara 
untuk menyelenggarakan pemerintahan. (Soemitro, $2007: 6$ ).

\section{Asas-asas Pemungutan Pajak dan Fungsi Pajak}

Pemungutan pajak bagi rakyat dilandasi oleh asas-asas sebagai berikut : (Brotodihardjo, 2006 : 37-43 ).

a. Asas Yuridis

b. Asas Ekonomis

c. Asas Finansial

Dalam kaitannya dengan sistem ekonomi suatu Negara, ada beberapa prinsip pengenaan pajak yang baik menurut Adam Smith yang dikenal dengan nama "Four Canon of Taxation" atau "The Four Maxims" yaitu: Equality, Certainty, Conveniance, dan Economy, masing masing dijelaskan sebagai berikut :
1. Prinsip Kesamaan/keadilan (equality)
2. Prinsip Kepastian (Certainty)
3. Prinsip Ekonomi (economy)

\section{Fungsi Pajak}

Menurut para ahli perpajakan, pajak memiliki dua fungsi utama yang saling melengkapi yaitu : (Mardiasmo, Edisi Revisi 2011 : 1 ).

1. Fungsi Budgetair

2. Fungsi Regulered

Fungsi regulerend dalam tax reform 2000 diatur dalam pasal 31 A Undang-undang Nomor 17 tahun 2000 yaitu : " Kepada wajib pajak yang melakukan penanaman modal di bidang-bidang usaha tertentu dan atau daerah tertentu dapat diberikan fasilitas perpajakan dalam bentuk :
a. Pengurangan penghasilan neto paling tinggi $30 \%$ dari jumlah penanaman yang dilakukan.
b. Penyusutan dan amortisasi yang di percepat.
c. Konpensasi kerugian yang lebih lama tetapi tidak lebih dari 10 tahun.
d. Pengenaan pajak penghasilan atas
deviden sebagimana dimaksud dalam
pasal 26 sebesar $10 \%$, kecuali apabila
tariff menurut perjanjian perpajakan

\author{
yang berlaku menetapkan lebih \\ rendah.
}

\section{Sistem Pemungutan Pajak}

Sistem pemungutan pajak di Indonesia di bagi menjadi tiga antara lain (Box center Indonesia ) :

1. .Sistem Self Assessment

2. 2.Sistem Official Assessment

3. SistemWitholding

\section{Perpajakan di Indonesia}

Perpajakan di Indonesia didasarkan pada Undang-undang Dasar 1945 Pasal 23 ayat (2) yang menyatakan, "Segala pajak untuk keperluan Negara ditetapkan dengan undang-undang". Dalam perkembangannya, undang-undang perpajakan di Indonesia telah beberpa kali mengalami perubahan. Awal dilakukannya reformasi perpajakan adalah pada tahun 1983 dengan ditetapkannya beberapa undang-undang perpajakan, diinanantaranya adalah sebagai berikut : ( Dawam, 2005: 1 ).

Satu undang-undang hasil tax reform tahun 1985 yaitu UU RI NO 17 tahun 1985 tentang bea materai, satu undang undang hasil tax reform tahun 1994 yaitu UU RI NO 17 tahun 1994 tentang perubahan atas undangundang no 12 tahun 1985 tentang pajak bumi dan bangunan, dan satu undang-undang hasil tax reform tahun 2002 yaitu UU RI NO 14 tahun 2002 tentang pengadilan pajak sebagai pengganti undang-undang no 17 thn 1997 tentang badan penyelesaian sengketa pajak . Pada tahun 2007 telah ditetapkan undangundang No. 28 tahun 2007 tanggal 17 Juli 2007 tentang ketentuan umum dan tata cara perpajakan sebagai perubahan atas Undangundang nomor 16 tahun 2000 yang mulai diberlakukan pada tanggal 1 Januari 2008.

Di dalam susunan pemerintahan Republik Indonesia, perpajakan dikelola oleh Departemen Keuangan Republik Indonesia yang operasionalnya di lakukan oleh direktorat Jenderal Pajak. Sedangkan jenisjenis Pajak yang dikelola oleh Direktorat Jenderal Pajak adalah sebagai berikut:

$$
\text { 1) Pajak Dalam Negeri }
$$


a). Pajak Penghasilan Non Migas

b) Pajak Penghasilan Migas ( Penulis

Direktorat Jenderal Pajak)

Faktor yang mempengaruhi Penerimaan Pajak

Secara garis besar terdapat dua faktor yang mempengaruhi penerimaan Pajak yaitu faktor internal dan faktor eksternal. Faktor internal adalah faktor yang berkaitan dengan direktorat jenderal Pajak sendiri yang berupa keterbatasan akses terhadap data wajib Pajak, data wajib Pajak belum seluruhnya terekam pada system yang ada, jumlah pegawai tidak sebanding dengan jumlah Wajib Pajak, dan adanya pembebasan Pajak bagi pengusaha tertentu. Faktor Eksternal yang mempengaruhi penerimaan Pajak diantaranya adalah faktor Wajib Pajak dan faktor makro ekonomi. Dari wajib Pajak berupa rendahnya kepatuhan wajib Pajak untuk melaporkan pajaknya dengan benar, adanya usaha penghindaran Pajak dengan melakukan tax planning, dan adanya wajib Pajak yang tidak melaporkan kegiatan usahanya.(Suparmoko,2005: 18)

Secara makro, kondisi-kondisi makro ekonomi tertentu berpengaruh terhadap penerimaan Pajak. Faktor makro ekonomi tersebut diantaranya adalah sebagai berikut

1. Nilai Tukar Rupiah

2. Tingkat Suku Bunga

3. Pertumbuhan ekonomi

4. Harga Minyak di pasar Internasional.

\section{Nilai Tukar Mata Uang}

\section{Pengertian/Definisi Nilai Tukar Mata Uang} atau Kurs

Konsep penentuan kurs diawali dengan konsep Purchasing Power Parity ( PPP ) yang pertama kali dikemukakan oleh Gustav Cassell 1922, : 2 ) kemudian berkembang konsep dengan pendekatan neraca pembayaran ( balance of payment theory ), dan konsep selanjutnya adalah pendekatan moneter (monetary approach).
Nilai mata uang dari suatu negara yang cenderung menurun menunjukkan negara tersebut mempunyai tingkat inflasi yang tinggi. Inflasi suatu negara lebih tinggi dibandingkan dengan negara lain berarti harga barang-barang di negara tersebut naik lebih cepat dari negara lain. Hal ini akan berakibat ekspor akan turun dan impor akan naik karena harga barang-barang negara bersangkutan lebih mahal bila dibandingkan dengan barangbarang negara lain. Dengan demikian supply dari mata uang asing akan turun dan demand akan naik, sehingga nilai mata uang asing akan naik (nilai mata uang domestik akan turun atau terdepresiasi).

Nilai tukar rupiah adalah harga rupiah terhadap mata uang negara lain. Kebijakan nilai tukar rupiah dilakukan untuk mengendalikan transaksi neraca pembayaran. Krisis ekonomi yang dialami oleh Indonesia dan beberapa negara Asia lainnya diawali dengan jatuhnya nilai tukar rupiah dan mata uang asing lainnya terhadap nilai dolar Amerika.

Pengaruh Nilai Tukar terhadap Penerimaan Pajak di Indonesia

Asumsi nilai tukar (kurs) rupiah terhadap dolar AS dibutuhkan untuk merupiahkan pos-pos penerimaan dan pengeluaran dalam RAPBN maupun Anggaran Pendapatan dan Belanja negara (APBN )yang nilai aslinya dalam dolar AS. Pos penerimaan dalam RAPBN maupun Anggaran Pendapatan dan Belanja negara (APBN) yang nilainya dalam dolar AS adalah Penerimaan Negara Bukan Pajak (PNBP) yang antara lain dari ekspor baik migas maupun non-migas. Di samping itu ada juga penerimaan dari pajak yang dalam hal ini bisa dari $\mathrm{PPh}$ maupun PPN hasil ekspor migas maupun non -migas.

Dalam kondisi kurs yang stabil akan mendorong dunia usaha menjalankan kegiatannya dengan tenang khusunya bagi usaha yang menggunakan valuta asing dalam transaksinya. Fluktuasi kurs yang ekstrim dapat mengakibatkan perusahaan merugi atau bahkan kolaps dan tidak dapat melanjutkan kegiatan usahanya. Dalam menghitung 
penghasilan neto untuk kepentingan perpajakan, kerugian akibat selisih kurs merupakan biaya yang dapat dikurangkan dari penghasilan bruto sehingga semakin besar kerugian akibat selisih kurs maka semakin kecil keuntungan yang diperoleh perusahaan sehingga Pajak Penghasilan yang dibayar juga semakin kecil. (Dietrich Lerche, $2007: 1)$

\section{Tingkat Suku Bunga}

\section{Pengertian Suku Bunga.}

Menurut (Hubbard ,1997 : 2 ) dalam (Laksmono, 2001 : 31), bunga adalah biaya yang harus dibayar borrower atas pinjaman yang diterima daqn imbalan lender atas investasinya. Suku bunga mempengaruhi keputusan individu terhadap pilihan membelanjakan uang lebih banyak atau menabung. Menurut (Kern dan Guttman, 1992 : 16 ) seperti diuraikan Laksmono (2001 : 22) menganggap suku bunga merupakan sebuah harga dan sebagaimana harga lainnya maka tingkat suku bunga ditentukan oleh interaksi antara permintaan dan penawaran.

\section{Penentuan Suku Bunga di Indonesia}

Menurut ( Bond dan Kumiati, 1994 : 99) dalam ( Laksmono, 2001:130), suku bunga domestik sangat terkait dengan suku bunga rntemasional. Hal ini disebabkan baiknya akses pasar keuangan domestik terhadap pasar keuangan internasional dan kebijakan nilai tukar yang tidak fleksibel. Peningkatan akses tersebut telah mernperbesar kendala manajemen moneter Bank Indonesia. Setiap upaya untuk mempengaruhi money supply dengan meningkatkan suku bunga diatas suku bunga intemasional akan mendapat gangguan dari arus modal masuk berjangka pendek. Namun, Bank Indonesia terlihat dapat mempertahankan derajat kebebasan beberapa suku bunga domestik sehingga tetap dapat mempengaruhi suku bunga domestik tanpa merubah kebijakan nilai tukar.

Selain suku bunga intemasional, tingkat diskonto SBI juga merupakan faktor penting dalam penentuan suku bunga di Indonesia. Peningkatan diskonto SBl segera direspon oleh suku bunga PUAB (Pasar Uang Antar Bank), sedangkan respon suku bunga deposito baru muncul setelah 7 -8 bulan.

Faktor lain yang turut berpengaruh dalam penentuan suku bunga di Indonesia adalah kondisi likuiditas yang berdampak pada suku bunga PUAB dalam jangka pendek. Namun dalam jangka panjang akan mendorong arus modal masuk sehingga pengaruhnya terhadap suku bunga deposito dan suku bunga kredit lebih kecil.

\section{Kerangka Pemikiran}

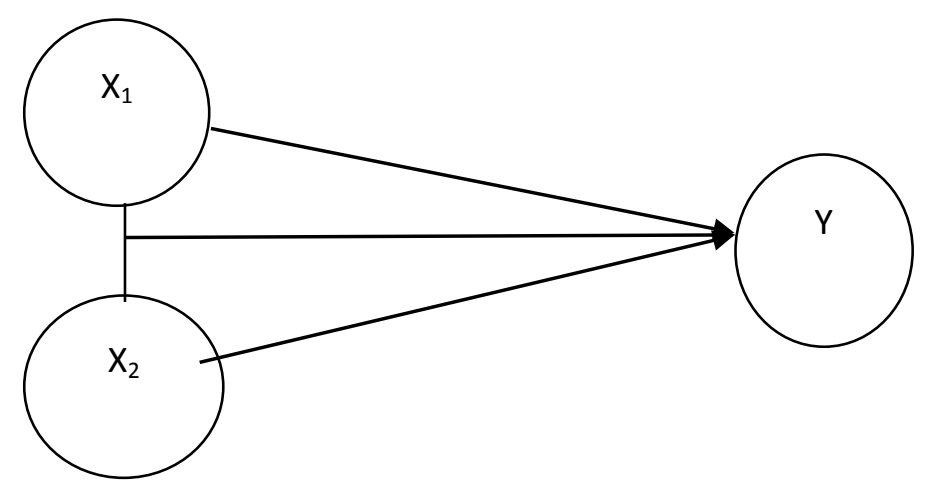

Dimana $\quad \mathrm{X}_{1} \quad$ : Nilai tukar rupiah

$\mathrm{X}_{2} \quad$ : Suku bunga

$\mathrm{Y}$ : Penerimaan Pajak 
Berdasarkan gambar kerangka pemikiran di atas, maka dapat dijelaskan sebagai berikut : Dalam Kondisi Perekonomian dengan kebijakan suku bunga yang kompetitif diharapkan kalangan pengusaha dapat memanfaatan dana yang ada pada bank atau lembaga keuangan untuk mengembangkan usahanya sehingga terdapat pertumbuhan ekonomi yang menyebabkan daya beli masyarakat meningkat dan penerimaan Pajak atas konsumsi barang dan jasa juga meningkat. Dengan adanya pertumbuhan ekonomi diharapkan nilai tukar rupiah terhadap mata uang asing menjadi lebih kuat dan stabil sehingga tidak menimbulkan kekhawatiran bagi pengusaha untuk bertransaksi denga menggunakan rupiah. Dalam jangka panjang, kestabilan nilai tukar rupiah akan mendorong pengusaha untuk mencukupi kebutuhan usaha yang tidak didapatkan didalam negeri melalui impor barang, dan dengan impor barang berarti jumlah supply barang barangkebutuhan bertambah sehingga harga barang akan turun.

\section{Hipotesis Penelitian}

Berdasarkan uraian sebelumnya, data data yang ada, dan tujuan penelitian, maka, peneliti mempunyai dugaan bahwa:

1. Diduga terdapat pengaruh antara nilai tukar rupiah, secara bersama-sama (simultan) berpengaruh signifikan terhadap penerimaan pajak.

2. Diduga terdapat pengaruh antara Tingkat Suku Bunga,secara bersamasama (Simultan) berpengaruh signifikan terhadap penerimaan pajak.

3. Diduga terdapat pengaruh antara nilai Tukar Rupiah dan Tingkat Suku Bunga,secara bersama-sama (Simultan) berpengaruh signifikan terhadap penerimaan pajak

\section{Penelitian Terdahulu}

Berikut penelitian terdahulu yang dikaji dari Journal Ekonomi dan

Pembangunan Indonesia

1. Menurut Noer Azam Achsani dan Harry Frenky Nababan Journal Volume IX No. 01 Juli 2008 ( ISSN 1411-5212) bahwa :
Dampak Perubahan /pengaruh Kurs (PassThrough Effect) Terhadap Penerimaan Pajak dan Terhadap Tujuh Kelompok Indeks Harga Konsumen sangat berpengaruh.

2. Menurut Shinta Dewi Perwitasari dan Telisa Aulia Faliaty Journal Volume IX No. 01 Juli 2008 ( ISSN 1411-5212) Aliran Modal Portofolio dan Implikasinya Terhadap Pergerakan / Perubahan Nilai Tukar Rupiah terhadap Penerimaan pajak sangat berpengaruh (studi kasus 19972007)

3. Menurut Nuning Trihadmini dan Pudjiastuti B.S.W Journal Volume XI No.2 Januari 2011 (ISSN 1411-5212) bahwa : Dampak Indeks Saham, Kurs dan Nilai Tukar Rupiah berpengaruh terdapat penerimaan pajak

\section{METODE PENELITIAN}

Penelitian dilakukan dengan menggunakan data sekunder yang terdapat pada Badan Pusat Statistik (BPS), Bank Indonesia, dan Direktorat Jenderal Pajak. Penelitian dilakukan dengan menggunakan metode studi kepustakaan (library research) karena penelitian dengan metode langsung tidak sepenuhnya dapat dilaksanakan dikarenakan keterbatasan waktu dan tenaga.

Variabel data yang akan diteliti dalam tesis ini adalah variabel bebas (independent) yakni laju nilai tukar rupiah terhadap dollar amerika $\left(\mathrm{X}_{1}\right)$, dan suku bunga Sertifikat Bank Indonesia (SBI) 3 bulanan $\left(\mathrm{X}_{2}\right)$. Sedangkan variabel tidak bebas (dependent) dalam penelitian ini adalah penerimaan pajak (Y). Variabel bebas (independent) dan variabel tidak bebas (dependent) diukur menggunakan skala interval atau rasio.

Populasi yang digunakan pada penelitian ini adalah nilai tukar rupiah, dan tingkat suku bunga yang ada di Indonesia. Sedangkan sampel data yang digunakan dalam penelitian ini adalah data data penerimaan pajak, nilai tukar rupiah terhadap dolar Amerika Serikat (kurs tengah), dan tingkat suku bunga SBI 3 bulanan dari triwulan I tahun 1997 sampai dengan triwulan IV 2006. Data-data tersebut dikumpulkan dengan teknik dokumentasi kemudian 
diseleksi dan digunakan sesuai dengan keperluan analisis. Data yang digunakan adalah laju nilai tukar rupiah terhadap dollar Amerika dan tingkat suku bunga SBI 3 bulan (Bank Indonesia) dan Penerimaan Pajak (Ditjen Pajak Departemen Keuangan).

Untuk mengetahui laju nilai tukar rupiah dan tingkat suku bunga SBI mempunyai pengaruh nyata (signifikan) terhadap penerimaan pajak, peneliti menggunakan model analisis dengan persamaan sebagai berikut :

$$
\mathrm{Y}=\mathrm{f}\left(\mathrm{X}_{1}, \mathrm{X}_{2},\right)
$$

Model analisis regresi linier berganda dibentuk dari persamaan tersebut menjadi :

$$
Y=\alpha+\beta_{1} X_{1}+\beta_{2} X_{2}+e
$$

\section{Dimana :}

dollar.

$$
\begin{array}{ll}
\mathrm{Y} & =\text { Penerimaan pajak. } \\
\mathrm{X}_{1} & =\text { Nilai tukar rupiah terhadap }
\end{array}
$$

bulan

dihitung.

$$
\alpha, \beta_{\mathrm{i}} \quad=\text { Parameter yang akan }
$$

$$
\mathrm{E}=\text { Kesalahan pengganggu. }
$$

\section{HASIL DAN PEMBAHASAN \\ Gambaran Umum Penerimaan Pajak}

Secara umum penerimaan pajak di Indonesia selalu meningkat dari tahun ke tahun karena kegiatan Ekstensifikasi maupun Intensifikasi aparat Perpajakan. Dalam kurun waktu 14 tahun terakhir, penerimaan pajak mengalami petumbuhan rata-rata sebesar 21,60\% sedangkan pertumbuhan rata-rata PDB adalah sebesar 21,21 \% (http://www.pajak.go.id).

Berikut disajikan data-data yang digunakan penulis dalam melakukan penelitian, sebagai berikut :

Pertama, penerimaan pajak. Angka yang digunakan dalam penelitian ini adalah penerimaan pajak secara keseluruhan (termasuk migas) yang diambil pada

\begin{tabular}{|c|c|c|c|c|}
\hline \multirow{2}{*}{ Tahun } & \multicolumn{4}{|l|}{ Triwulan } \\
\hline & I & II & III & IV \\
\hline 1997 & $26,695,804$ & $18,233,793$ & $20,732,342$ & $24,073,956$ \\
\hline 1998 & $38,434,885$ & $27,139,261$ & $42,566,310$ & $37,547,569$ \\
\hline 1999 & $36,414,016$ & $31,413,511$ & $42,585,137$ & $35,451,500$ \\
\hline 2000 & $61,846,699$ & $40,643,854$ & $56,504,082$ & $94,688,290$ \\
\hline 2001 & $44,823,558$ & $45,459,046$ & $42,765,214$ & $53,062,046$ \\
\hline 2002 & $47,822,017$ & $47,737,304$ & $49,873,760$ & $63,512,727$ \\
\hline 2003 & $57,081,278$ & $49,560,165$ & $55,843,079$ & $77,796,892$ \\
\hline 2004 & $60,064,586$ & $58,844,380$ & $65,580,002$ & $96,384,837$ \\
\hline 2005 & $74,228,909$ & $75,953,708$ & $84,107,271$ & $82,543,839$ \\
\hline 2006 & $88,585,493$ & $94,511,492$ & $99,281,514$ & $126,675,857$ \\
\hline
\end{tabular}
setiap akhir triwulan sebagai berikut:

Tabel 1

Penerimaan Pajak

Triwulan I tahun 1997 s.d Triwulan IV tahun 2006

( Dalam jutaan rupiah )

Nilai Tukar Rupiah. Dalam hal ini penulis menggunakan nilai tukar rupiah terhadap dollar Amerika karena mata uang tersebut dianggap salah satu mata uang asing yang paling banyak digunakan oleh negara-negara di dunia dan menjadi pedoman dalam perdagangan internasional. Data perkembangan nilai tukar rupiah 
terhadap dolar Amerika tahun 1997 s.d 2006 adalah sebagai berikut pada tabel 2 :

Tingkat suku bunga. Berikut adalah data perkembangan suku bunga Sertifikat
Bank Indonesia per 3 bulan yang dirangkum dari tahun 1997 s.d 2006.

Tabel 2

Kurs Tengah Bank Indonesia

( Rupiah terhadap Dolar Amerika Serikat )

Triwulan I tahun 1997 s.d Triwulan IV tahun 2006

\begin{tabular}{|l|r|r|r|r|}
\hline \multirow{2}{*}{ Tahun } & \multicolumn{4}{l}{ Triwulan } \\
\cline { 2 - 5 } & I & \multicolumn{1}{l|}{ II } & \multicolumn{1}{l|}{ III } & \multicolumn{1}{l|}{} \\
\hline 1997 & $2,407.00$ & $2,441.00$ & $2,969.67$ & $3,989.33$ \\
\hline 1998 & $9,150.00$ & $11,131.67$ & $11,591.67$ & $7,625.00$ \\
\hline 1999 & $8,788.33$ & $7,697.00$ & $7,608.67$ & $7,141.67$ \\
\hline 2000 & $7,506.67$ & $8,433.33$ & $8,691.00$ & $9,506.67$ \\
\hline 2001 & $9,895.00$ & $11,391.00$ & $9,355.00$ & $10,421.67$ \\
\hline 2002 & $10,054.67$ & $8,943.67$ & $8,996.67$ & $9,049.67$ \\
\hline 2003 & $8,896.33$ & $8,413.00$ & $8,476.33$ & $8,499.00$ \\
\hline 2004 & $8,491.67$ & $9,095.33$ & $9,222.00$ & $9,132.67$ \\
\hline 2005 & $9,301.67$ & $9,592.67$ & $10,123.00$ & $9,985.00$ \\
\hline 2006 & $9,233.33$ & $9,098.33$ & $9,135.00$ & $9,098.33$ \\
\hline
\end{tabular}

Sumber : Bank

Indonesia

Tabel 3

Tingkat Suku Bunga Bank Indonesia

Triwulan I tahun 1997 s.d Triwulan IV tahun 2006

\begin{tabular}{|l|r|r|r|r|}
\hline \multirow{2}{*}{ Tahun } & \multicolumn{5}{|l|}{ Triwulan } & \multicolumn{2}{l|}{} \\
\cline { 2 - 5 } & I & II & III & 18.00 \\
\hline 1997 & 12.48 & 11.29 & 21.67 & 49.06 \\
\hline 1998 & 22.67 & 40.67 & 44.00 & 12.93 \\
\hline 1999 & 37.08 & 29.58 & 13.95 & 13.90 \\
\hline 2000 & 11.14 & 10.98 & 13.22 & 17.62 \\
\hline 2001 & 14.86 & 15.95 & 17.18 & 14.56 \\
\hline 2002 & 17.11 & 16.07 & 14.68 & 8.38 \\
\hline 2003 & 12.53 & 10.78 & 9.00 & 7.30 \\
\hline 2004 & 7.73 & 7.25 & 7.30 & 12.58 \\
\hline 2005 & 7.29 & 7.79 & 8.98 & 10.39 \\
\hline 2006 & 12.86 & 12.49 & 12.16 & \\
\hline
\end{tabular}

Sumber : Bank

Indonesia 


\section{Pengujian Asumsi Klasik.}

Pengujian asumsi klasik terhadap model yang telah di susun adalah untuk mengetahui apakah model linier berganda yang telah dibentuk telah memenuhi kriteria Best Linear Unbiased Estimator (BLUE), yaitu regresi linier berganda telah memenuhi pengujian linieritas, residual mengikuti distribusi normal, tidak terdapat gejala multikolonieritas, tidak dapat disimpulkan apakah terdapat autokorelasi atau tidak terdapat autokorelasi, dan tidak terdapat masalah heterokedastisitas. Jika asumsi klasik model regresi linier telah terpenuhi semua maka penaksiran model regresi berganda tersebut telah memenuhi BLUE, artinya penaksiran tidak bias linear dan konsisten,

Tabel 4-16

mempunyai varians yang minimum atau secara sederhana model tersebut telah valid dan reliable (Gujarati. 1997).

Uji Normalitas.

Tujuan asumsi normalitas adalah untuk menguji apakah dalam sebuah model regresi, variabel dependen, variabel independen atau keduanya mempunyai distribusi yang normal atau tidak. Model regresi yang baik adalah mempunyai distribusi normal atau mendekati normal. Untuk menguji normalitas dalam penelitian ini dilakukan dengan menggunakan bantuan software SPSS yaitu dengan melakukan pengamatan terhadap Normal PP plot. Adapun hasil pengolahan data seperti terlihat pada gambar berikut :

Hasil Uji Normalitas

\begin{tabular}{|l|l|l|l|l|}
\hline & \multicolumn{3}{|l|}{ Skewness } & \multicolumn{2}{l|}{ Kurtois } \\
\hline $\begin{array}{l}\text { Unstandardized } \\
\text { Residual }\end{array}$ & Statistic & Std.Eror & Statistic & Std.Eror \\
\hline Valid N (Listwise) & .004 & .687 & 3.134 & 1.334 \\
\hline
\end{tabular}

Sumber : pengelolaan spss 17

Terlihat pada hasil uji normalitas di atas bahwa rasio Skewness $=0,004 / 0,687=$ 5,822 , sedangkn rasio Kurtois = 3,314 / 1,334 $=2,484$, maka rasio skewness dan rasio kurtois berada diantara -2 hingga +2 , dan hal ini dapat disimpulkan pengaruh kurs nilai tukar dan tingkat bunga terhadap penerimaan pajak atas distribusi data adalah normal.

\section{Uji Multikolinieritas.}

Pengujian selanjutnya dari asumsi klasik adalah pengujian ada atau tidak gejala multikolinieritas. Asumsi metode regresi linier berganda klasik adalah tidak terjadi multikolinieritas antar sesama variable. Deteksi ada tidaknya multikolinearitas dilakukan dengan jalan melihat besaran VIF ( Variance Inflation Factor ) dan Tolerance serta koefisien korelasi antara variabel independen.

Tabel 4-17

Hasil Pengujian Multikolinieritas

(Matriks Korelasi)

\begin{tabular}{|c|c|c|c|c|c|c|c|c|}
\hline \multirow{2}{*}{\multicolumn{2}{|c|}{ Model }} & \multicolumn{2}{|c|}{$\begin{array}{l}\text { Unstandardized } \\
\text { Coefficients }\end{array}$} & \multirow{2}{*}{$\begin{array}{l}\text { Standardi } \\
\text { zed } \\
\text { Coefficie } \\
\text { nts } \\
\text { Beta }\end{array}$} & \multirow[t]{2}{*}{$\mathrm{t}$} & \multirow[t]{2}{*}{ Sig. } & \multicolumn{2}{|c|}{$\begin{array}{l}\text { Collinearity } \\
\text { Statistics }\end{array}$} \\
\hline & & B & Std. Error & & & & $\begin{array}{l}\text { Toler } \\
\text { ance }\end{array}$ & VIF \\
\hline \multirow[t]{2}{*}{1} & $\begin{array}{l}\text { (Constant } \\
\text { ) }\end{array}$ & $1.932 \mathrm{E} 8$ & $1.864 \mathrm{E} 8$ & & $\begin{array}{l}1.03 \\
7\end{array}$ & .004 & & \\
\hline & Kurs & 3877.373 & 3910.134 & .327 & .992 & .006 & .403 & $\begin{array}{l}1.10 \\
8\end{array}$ \\
\hline
\end{tabular}




\begin{tabular}{|l|l|l|l|l|l|l|l|l|}
\hline & Bunga & $\begin{array}{l}-.365 \\
1925692.27 \\
4\end{array}$ & $\begin{array}{l}1738920 . \\
773\end{array}$ & $\begin{array}{l}1.10 \\
7\end{array}$ & .009 & .303 & $\begin{array}{l}1.10 \\
8\end{array}$ \\
\hline
\end{tabular}

\section{Sumber : pengelolahan SPSS 17}

Berdasarkan matrik korelasi antara variabel independen dengan variabel dependen lainnya seperti terlihat pada tabel 4-6, maka tidak terdapat korelasi yang kuat antara variabel independen $\mathrm{X}_{2}$ dengan $\mathrm{X}_{1}$ berkorelasi, Sehingga dapat disimpulkan bahwa model tidak terdapat gejala multikolinieritas.

Uji Autokorelasi.

Pengujian asumsi klasik yang selanjutnya adalah penyimpangan asumsi klasik gejala autokorelasi. Kondisi autokorelasi bertitik tolak dari adanya gangguan-gangguan pada hubungan antar variabel.
Salah satu metode untuk mendeteksi adanya gejala autokorelasi adalah metode atau uji Durbin Watson (Durbin Watson Test). Cara pengujian dilakukan dengan melihat angka Durbin Watson hasil perhitungan (Nachrowi : 2008).

Dari hasil perhitungan, nilai Durbin Watson (DW) dari objek penelitian menghasilkan nilai DW sebesar 1,122. Sedangkan dari tabel DW dengan observasi $(\mathrm{n})=40$ dan regressor $(\mathrm{k})=4$ dengan tingkat signifikan $\propto=1 \%$, dari tabel didapat $\mathrm{d}_{\mathrm{L}}$ sebesar 1.10 dan $d_{u}$ sebesar 1.52. Nilai d (DW) observasi berada antara daerah ragu yaitu antara $1,10 \leq 1,122 \leq 1,52$ seperti yang terlihat pada gambar 4.2 berikut ini :

Tabel 4-18

Hasil Pengujian Durbin Watson (DW)

\begin{tabular}{|l|l|l|l|l|l|}
\hline $\begin{array}{l}\text { Mod } \\
\text { el }\end{array}$ & $\mathrm{R}$ & $\begin{array}{l}\mathrm{R} \\
\text { Square }\end{array}$ & $\begin{array}{l}\text { Adjusted } \\
\text { R Square }\end{array}$ & $\begin{array}{l}\text { Std. Error of } \\
\text { the Estimate }\end{array}$ & $\begin{array}{l}\text { Durbin- } \\
\text { Watson }\end{array}$ \\
\hline 1 & $.000^{\mathrm{a}}$ & .000 & -.286 & $\begin{array}{l}9.28790627 \\
\mathrm{E7}\end{array}$ & 1.211 \\
\hline
\end{tabular}

\section{Sumber : Pengolahan Spss 17}

Nilai d (D-W) berada di daerah keraguan, sehingga dapat disimpulkan bahwa pengujian tidak dapat menyimpulkan adanya autokorelasi ataupun tidak adanya autokorelasi. Namun demikian secara umum apabila hasil pengujian tidak berada pada autokorelasi positif atau autokorelasi negatif dapat dikatakan bahwa model regresi tidak terdapat autokorelasi ( Nachrowi : 2008 ). Pada model seperti ini berkorelasi positif mengandung makna bahwa jika salah satu variabel bebas bergerak naik maka variabel bebas lainnya juga bergerak naik atau bergerak searah, ( Gujarati : 2008).

\section{Uji Heterokedastisitas.}

Untuk uji Heteroskededastisitas, seperti halnya uji normalitas, ini untuk menentukan apakah suatu model terbebas dari masalah Heteroskededastisitasatau tidak dengan melihat pada Scatter Plot dan dilihat apakah resiudual memiliki pola tertenutu atau tidak. Pengujian yang digunakan dalam mendeteksi adanya gejala heteroskedastisitas dapat dilakukan dengan uji Glejser.

Tabel 4-19

Hasil Pengujian Heteroskedastisitas

\begin{tabular}{|l|l|l|l|l|l|l|}
\hline \multicolumn{2}{|l|}{ Model } & \multicolumn{2}{|l|}{$\begin{array}{l}\text { Unstandardized } \\
\text { Coefficients }\end{array}$} & $\begin{array}{l}\text { Standardized } \\
\text { Coefficients }\end{array}$ & T & Sig. \\
\cline { 3 - 7 } \multicolumn{2}{l|}{} & B & Std. Error & Beta & & \\
\hline \multirow{2}{*}{1} & $\begin{array}{l}\text { (Constant } \\
\end{array}$ & $2.956 \mathrm{E} 7$ & $1.361 \mathrm{E} 8$ & & .217 & .834 \\
\cline { 2 - 7 } & Kurs & 1525.657 & 2855.158 & .202 & .534 & .610 \\
\cline { 2 - 7 } & Bunga & - & 1269750.12 & -.178 & -.472 & .652 \\
\hline
\end{tabular}




\begin{tabular}{|l|l|l|l|l|l|l|}
\hline & & 598785.682 & 9 & & & \\
\hline
\end{tabular}

Sumber : Pengolahan Data Spss 17

Uji dari seluruh variable tidak ada yang signifikansi secara statistic, sehingga dapat dikatakan bahwa model ini tidak mengalami masalah Heteroskedastisitas.

\section{Analisis Model}

Teknik analisis yang digunakan dalam penelitian ini adalah analisis regresi linier berganda, yang mana variabel terikat. Teknik analisis yang digunakan dalam penelitian ini adalah analisis regresi linier berganda, yang mana variabel tergantung (dependent variable) adalah penerimaan pajak, sedangkan variabel bebas (independent variable) adalah laju inflasi, nilai tukar rupiah dan tingkat suku bunga SBI 3 bulan. Data tersebut diolah dengan menggunakan program SPSS dengan hasil terlihat pada tabel di bawah ini (ringkasan hasil regresi linier berganda).

Tabel 4-12

Hasil Analisis Regresi Linier Berganda Tiga Variabel Bebas

Terhadap Penerimaan Pajak

\begin{tabular}{|l|l|l|l|}
\hline Variabel & Koefisien Regresi & T & Sign \\
\hline Konstan & $1,932 \mathrm{E} 8$ & 1.0374 & 0.004 \\
\hline Kurs & 3877.373 & 0.992 & 0.006 \\
\hline Bunga & -1925692.274 & 1,107 & 0.009 \\
\hline $\begin{array}{l}\text { Dependent Variabel } \\
\text { R }\end{array}$ & $=0,560^{\mathrm{a}}$ \\
R Squere & $=0,314$ \\
F Hitung & $=1,603$ \\
DW & $=1,211 \quad$ Sign $=0,004$ \\
& \multicolumn{3}{|}{} \\
\hline
\end{tabular}

\section{Sumber : Data Sekunder Hasill Pengolahan Spss 17}

Berdasarkan hasil tabel analisis tersebut, maka model persamaan regresi linier berganda adalah sebagai berikut :

$\mathrm{Y}_{\mathrm{t}}=1,932 \mathrm{E} 8+3877.373 \mathrm{X}_{1}-1925692.274 \mathrm{X}_{3}$ Dari persamaan regresi linier berganda di atas diketahui :

Koefisien regresi sebesar 1,932E8 menunjukkan bahwa variabel Kurs nilai tukar Rupiah berpengaruh terhadap penerimaan atas pajak didirektorat pajak. Hal ini menjelaskan bahwa semakin tinggi nilai tukar Rupiah, maka akan berdampak pada meningkatnya penerimaan pajak. Atau dengan kata lain,setiap bertambah untuk Nilai tukar, maka akan meningkatkan penerimaan pajak sebesar 1,932E8 juta.
Koefisien regresi sebesar 3877.373 menunjukkan bahwa variabel jumlah tingkat suku Bunga atau lebih signifikan terhadap penerimaan pajak. Hal ini berarti semakin tinggi tingkat suku Bunga, maka akan berdampak pada meningkatnya penerimaan pajak. Dari tabel 4- 12 Nilai korelasi (R) sebesar 0,560 menunjukkan variabel bebas yang dimasukkan dalam persamaan regresi secara bersama-sama mempunyai hubungan yang cukup erat dan memiliki arah yang sama terhadap perubahan penerimaan pajak (Y). Hal tersebut dikarenakan angka korelasi yang dihasilkan oleh model nilainya mendekati 1 .

Sementara itu nilai koefisien determinasi yang ditunjukkan oleh nilai dari $R$ 
square $\left(\mathrm{R}^{2}\right)$ menghasilkan besaran sebesar 0,314 yang mengandung pengertian bahwa $31,40 \%$ (persen), dari perubahan penerimaan pajak (Y) dijelaskan oleh variabel bebas yang terbentuk dalam model (nilai tukar rupiah dan sertifikat Bank Indonesia 3 bulan), sedangkan sisanya $68,60 \%$ (persen) dipengaruhi variabel lain yang tidak termasuk dalam model.

Tabel 4-13

Hasil Analisis Korelasi Tiga Variabel Bebas

Terhadap Penerimaan Pajak

\begin{tabular}{|l|l|l|l|}
\hline Variabel & $\mathrm{Y}$ & $\mathrm{X}_{1}$ & $\mathrm{X}_{2}$ \\
\hline $\mathrm{Y}$ & 1.0000 & & \\
\hline $\mathrm{X}_{1}$ & 0,440 & 1.0000 & \\
\hline $\mathrm{X}_{2}$ & $-0,467$ & $-0,312$ & 1.0000 \\
\hline
\end{tabular}

Sumber : Pengolahan Spss 17

Untuk melihat kekuatan hubungan (korelasi) variabel independen terhadap variabel dependen dapat dilihat melalui besaran korelasi variabel independen terhadap variabel dependen. Berdasarkan penghitungan korelasi antara variabel independen dengan variabel dependen terlihat bahwa variabel yang memiliki korelasi relatif besar terhadap penerimaan pajak adalah variabel nilai tukar rupiah $\left(\mathrm{X}_{1}\right)$. Variabel nilai tukar rupiah memiliki korelasi sedang dan searah yaitu $44,00 \%$ (persen). Korelasi terbesar kedua dari variabel dependen adalah variabel tingkat suku bunga SBI. Variabel ini memiliki korelasi sedang namun tidak searah yaitu sebesar 56,00\% (persen), Hasil korelasi antara tiga variabel bebas terhadap penerimaan pajak.

\section{Pembuktian Hipotesis}

Uji t-test digunakan untuk menguji signifikansi pengaruh variabel independen secara parsial terhadap variabel dependen. Hipotesis statistik yang diajukan dalam penelitian ini dirumuskan sbb :

$\mathrm{H}_{0}:$ bi $=0$ : tidak ada pengaruh

$\mathrm{H}_{1}$ : $\mathrm{bi} \neq 0$ : ada pengaruh

Signifikan tidaknya pengaruh variabel independen secara parsial terhadap variabel dependen dilakukan dengan melihat probabilitas (nilai sig.) dari $\mathrm{t}$ rasio seluruh variabel bebas pada taraf uji $\alpha=5 \%$.

Tabel 4-14

Hasil Pengujian t-Test

\begin{tabular}{|l|l|l|l|}
\hline Variabel & t-hitung & Sig. & Keterangan \\
\hline Konstan & 1.0374 & 0,004 & Siginifikan pada $\propto=0,05(5 \%)$ \\
\hline $\begin{array}{l}\text { Kurs (nilai tular } \\
\text { rupiah) }\end{array}$ & 0.992 & 0,006 & Siginifikan pada $\propto=0,05(5 \%)$ \\
\hline Bunga (SBI 3 bulan) & 1,107 & 0,009 & Siginifikan pada $\propto=0,05(5 \%)$ \\
\hline
\end{tabular}

Dasar pengambilan keputusan :

Dengan membandingkan nilai t hitung dengan $\mathrm{t}$ table
- Apabila t hitung > t tabel, maka H0 ditolak dengan $\mathrm{H} 1$ diterima.

- Apabila $\mathrm{t}$ hitung < $\mathrm{t}$ tabel, maka H0 diterima. 
b. Dengan angka signifikansi 95 persen ( $\alpha=$ 0,05 ) dan nilai df (degree of

freedom) $\mathrm{n}-\mathrm{k}=(10-4)=6$, maka dapat diketahui nilai t tabel sebesar 2,099.

Dari Penjelasan table 4-14 pada pengujian (uji t) di atas diketahui :

Variabel Nilai Tukar Rupiah Terhadap Penerimaan Pajak $\left(\mathrm{X}_{1}\right)$

Berdasarkan perhitungan diketahui bahwa hasil output regresi variable transfer ( X1 ) menunjukkan $\mathrm{t}$ hitung sebesar 1,932E8 $(1,932 \mathrm{E} 8>2,099)$ dengan angka signifikansi sebesar 0,006 $(0,006<0,05)$ maka dapat disimpulkan bahwa variable tranfer secara signifikan berpengaruh positif terhadap variabel penerimaan pajak (Y).. Hal ini menjelaskan bahwa semakin tinggi jumlah kurs nilai tukar akan berdampak pada meningkatnya penerimaan $\operatorname{pajak}(\mathrm{Y})$.

Variabel Tingkat Bunga Terhadap Penerimaan Pajak $\left(\mathrm{X}_{2}\right)$
Berdasarkan perhitungan diketahui bahwa hasil output regresi variable Tingkat Bunga ( $\mathrm{X} 2$ ) menunjukkan $\mathrm{t}$ hitung sebesar 1,107 $(1,107>2,132)$ dengan angka signifikansi sebesar 0,009 $(0,009<0,05)$ maka dapat disimpulkan bahwa variabel Tingkat Bunga secara signifikan berpengaruh positif terhadap variabel penerimaan Pajak (Y).

Pengujian Hipotesis Pengaruh Variabel Bebas Secara Simultan (Uji F)

Untuk mengetahui signifikan variabel bebas secara simultan, dapat dilakukan dengan cara membandingkan probabilitas (nilai Sig.) variabel bebas dengan derajat kepercayaan $5 \%$ atau $\alpha=0,05$. Apabila nilai Sig. variabel bebas lebih kecil dari $\alpha=0,05$ maka variabel tersebut signifikan pada tingkat kepercayaan 5\%, sebaliknya apabila lebih besar dari $\propto=0,05$ maka variabel tersebut tidak signifikan pada tingkat kepercayaan $5 \%$.

Tabel 4-15

Hasil Pengujian Simultan (Uji F)

\begin{tabular}{|c|c|c|c|c|c|c|}
\hline \multicolumn{2}{|c|}{ Model } & $\begin{array}{c}\text { Sum of } \\
\text { Squares }\end{array}$ & df & $\begin{array}{c}\text { Mean } \\
\text { Square }\end{array}$ & F & Sig. \\
\hline \multirow{3}{*}{1} & Regression & $2.766 \mathrm{E} 16$ & 2 & $1.383 \mathrm{E} 16$ & 1.603 & $.004^{\mathrm{a}}$ \\
\cline { 2 - 7 } & Residual & $6.039 \mathrm{E} 16$ & 7 & $8.627 \mathrm{E} 15$ & & \\
\cline { 2 - 8 } & Total & $8.804 \mathrm{E} 16$ & 9 & & & \\
\hline
\end{tabular}

Sumber : Pengolahan Spss 17

Berdasarkan hasil pengolahan data dan berdasarkan hasil penghitungan Analisis of Variance (ANOVA) seperti yang terlihat pada tabel 4-15 diperoleh nilai F Hitung.

Dasar pengambilan keputusan :

a. Dengan membandingkan nilai $F$ hitung dengan $\mathrm{F}$ table

- Apabila F hitung > F tabel, maka H0 ditolak atau $\mathrm{H} 1$ diterima

- Apabila F hitung < F tabel, maka H0 diterima

Dengan tingkat signifikansi 95 persen $(\alpha=$ $0,05)$ dan nilai df (degree of freedom) $\mathrm{n}-\mathrm{k}-$ $1=(10-4-1)=5$ maka dapat diketahui nilai $F$ tabel sebesar 1.603

b. Dengan menggunakan angka signifikansi

- Apabila angka signifikansi > 0,05 maka H0 diterima.
- Apabila angka signifikansi $<0,05$ maka H0 ditolak atau $\mathrm{H} 1$ diterima.

Hasil output regresi menunjukkan nilai $\mathrm{F}$ hitung sebesar 2.766E16 (2.766E16 > 1.603) dengan angka signifikansi sebesar 0,004 ( $0,004<0,05$ ) sehingga dapat disimpulkan bahwa ketiga variabel independen yaitu Kurs nilai tukar Rupiah dan tingkat suku bunga bersama - sama berpengaruh terhadap penerimaan pajak.

\section{PEMBAHASAN}

Berdasarkan hasil analisis regresi linier berganda tiga variabel bebas terhadap penerimaan pajak (Tabel 4-12) diperoleh hasil bahwa setiap kenaikan nilai tukar rupiah sebesar satu satuan akan mengakibatkan kenaikan penerimaan pajak sebesar 3877.373 
satuan dengan asumsi variabel bebas lainnya tetap. Sedangkan berdasarkan hasil analisis korelasi tiga variabel bebas terhadap penerimaan pajak (Tabel 4-13) diketahui bahwa korelasi antara nilai tukar rupiah dengan penerimaan pajak berkorelasi sebesar 44,00\%(persen) dengan sifat searah, artinya bahwa apabila terdapat kenaikan nilai tukar rupiah terhadap dolar Amerika maka penerimaan pajak diprediksi meningkat dengan besaran korelasi $56,00 \%$ atau sebaliknya.

Berdasarkan pengujian hipotesis variabel bebas secara parsial (uji-t) pada tabel 4-14 diperoleh hasil bahwa nilai tukar rupiah mempunyai pengaruh signifikan terhadap penerimaan pajak pada tingkat kepercayaan 0,005 atau $5 \%$. Dengan tingkat signifikansi sebesar $5 \%$ maka telah memenuhi syarat untuk diterimanya hipotesis bahwa nilai tukar rupiah berpengaruh terhadap penerimaan pajak (gujarati : 2007). Berdasarkan hasil pengujian diatas maka diketahui bahwa nilai tukar rupiah berpengaruh terhadap penerimaan pajak.

Berdasarkan hasil analisis regresi linier berganda tiga variabel bebas terhadap penerimaan pajak (Tabel 4-12) diperoleh hasil bahwa setiap kenaikan tingkat SBI 3 bulan sebesar satu satuan maka mengakibatkan penurunan penerimaan pajak sebesar 1925692.274 satuan dengan asumsi variabel bebas lainnya tetap. Sedangkan berdasarkan hasil analisis korelasi tiga variabel bebas terhadap penerimaan pajak (Tabel 4-13) diketahui bahwa korelasi antara tingkat SBI 3 bulan dengan penerimaan pajak berkorelasi sedang dan searah sebesar 56,00\% (persen).

Berdasarkan pengujian hipotesis variabel bebas secara parsial (uji-t) pada tabel 4-14 diperoleh hasil bahwa tingkat SBI 3 bulan mempunyai pengaruh signifikan terhadap penerimaan pajak pada tingkat kepercayaan 0.005 atau $5 \%$. Pada tingkat kepercayaan $5 \%$ berarti bahwa variabel bebas secara parsial berpengaruh signifikan terhadap variabel tidak bebas hingga $\mathrm{H}_{1}$ dapat diterima. Berdasarkan hasil pengujian diatas maka diketahui bahwa tingkat suku bunga berpengaruh terhadap penerimaan pajak.

\section{KESIMPULAN DAN SARAN}

\section{Kesimpulan}

Berdasarkan hasil analisa dan pembahasan yang dilakukan pada Bab sebelumnya, maka dapat disimpulkan bahwa :

1. Terdapat pengaruh antara nilai tukar rupiah dengan penerimaan pajak dengan pengaruh sebesar $47,90 \%$ dengan sifat searah (positif), dimana ketika dolar Amerika mengalami apresiasi terhadap rupiah maka perusahaan yang melakukan ekspor barang akan mendapatkan selisih lebih karena perbedaan kurs dan selisih lebih tersebut merupakan penghasilan yang merupakan objek Pajak.

2. Terdapat pengaruh antara tingkat suku bunga dengan penerimaan pajak sebesar $52,20 \%$ dengan sifat tidak searah (negatif), dimana ketika tingkat bunga tinggi maka biaya perusahaan akan naik (karena bunga adalah biaya) sehingga harga pokok naik, laba berkurang, dan pajak terutang berkurang.

3. Terdapat hubungan yang signifikan antara, nilai tukar rupiah, dan tingkat suku bunga secara bersama-sama terhadap penerimaan pajak dimana hasil analisis linier berganda tiga variabel menunjukkan nilai korelasi ( $\mathrm{R}$ ) yang dihasilkan model regresi nilainya mendekati 1 yaitu 0,560 .

\section{Saran} diatas maka penulis menyarankan untuk penelitian selanjutnya hendaknya :

1. Menambahkan faktor makro ekonomi lainnya seperti tingkat pertumbuhan ekonomi, tingkat harga minyak pada pasar internasional, tingkat produksi minyak dalam negeri, dan faktor kenaikan harga minyak pada pasaran dalam negeri. 
2. Untuk faktor makro ekonomi yang ternyata pengaruhnya tidak signifikan dapat tidak diikutkan dalam penelitian.

\section{DAFTAR PUSTAKA}

Soemitro, Rochmat, Azas dan Dasar Perpajakan, Bandung: Eresco, 1990

Sriyana Jaka dampak ekspansi fiskal terhadap inflasi studi empiris dengan pendekatan error correction model jurnal ekonomi pembangunan Volume 6 Nomor 22001

Simatupang Banjar kebijakan uang ketat peredam inflasi atau penyebab stagflasi analisis non struktural is jurnal keuangan dan moneter volume 3 nomor tiga Departemen Keuangan Republik Indonesia Jakarta 1996

Cuman Habi djaja Suparman dalam disertasinya pajak berdasarkan gotong royong Unpad Bandung 1964

Sukardi HP analisis residu untuk uji normalitas dan linieritas majalah ilmiah Spektra volume 7 No 8 Jakarta 2002

Samuelson makroekonomi edisi ke-14 Penerbit Erlangga Jakarta 2006

Santoso Singgih menguasai statistik di era informasi dengan SPSS 15 PTK Media komputindo Jakarta 2007

Sumitro Rahmat asas dan dasar perpajakan penerbit Eriko Bandung 1986

Sugiarto dan Herlambang Teddy ekonomi makro teori analisis dan kebijakan cetakan pertama penerbit PT Gramedia Pustaka Utama Jakarta 2001

Suharyadi dan Purwanto SK statistika untuk ekonomi dan keuangan makro edisi kedua penerbit PT Salemba emban Patria Jakarta 2007

Sukirno Sadono makro ekonomi modern penerbit Rajawali pers Jakarta 2000
Supranto statistik teori dan aplikasi buku 2 edisi 6 penerbit Erlangga Jakarta 2001

Waluyo perpajakan Indonesia jilid 1 dan 2 edisi 6 penerbit PT Salemba emban Patria Jakarta 2006

Wibisono Yusuf metode statistik cetakan pertama penerbit Gajah Mada University press Yogyakarta 2005

Amir Hidayat faktor-faktor yang mempengaruhi nilai tukar Rupiah kajian ekonomi dan keuangan Departemen Keuangan RI 2005

Badzmaru lemon dan fredrik inflasi tinjauan ekonomi politik inflasi perpajakan dan utang pemerintah jurnal ekonomi dan pembangunan Volume 5 Nomor 22000

Gudono analisis arah kausalitas kausal ordering jurnal ekonomi dan bisnis Indonesia volume 21 nomor $1 \mathrm{BPP}$ Yogyakarta 2006

Haryanto Sugeng faktor yang mempengaruhi jumlah uang beredar M2 di Indonesia pasca deregulasi perbankan 1988 jurnal penelitian Universitas Merdeka Malang volume 15 nomor 2 Malang 2003

Galih dan ban oon Sasmita Siwi Analisis pengaruh perubahan suku bunga terhadap kinerja makro ekonomi Indonesia periode 1993152 pendekatan jalur kredit dan Sar jurnal ekonomi dan bisnis Indonesia 21 nomor 4 BPP Yogyakarta 2006

suhaidi dkk suku bunga sebagai salah satu indikator ekspektasi inflasi buletin ekonomi moneter dan perbankan volume 2 Nomor 4 Bank Indonesia Jakarta 2000

Cahya Wandita hari dumairy pengendalian kurs Rupiah terhadap dolar Amerika Serikat melalui suku bunga SBI volume 18 Nomor 4 Jakarta 2005 